\title{
Protective roles of isoastilbin against Alzheimer's disease via Nrf2-mediated antioxidation and anti-apoptosis
}

\author{
HONG YU ${ }^{1 *}$, BO YUAN ${ }^{2 *}$, QIUBO CHU ${ }^{3}, \mathrm{CHUNYUE} \mathrm{WANG}^{3}$ and $\mathrm{HUI} \mathrm{BI}^{4}$ \\ Departments of ${ }^{1}$ Otolaryngology Head and Neck Surgery and ${ }^{2}$ Urology, The First Hospital of Jilin University, \\ Jilin University, Changchun, Jilin 130021; ${ }^{3}$ School of Life Sciences, Jilin University, Changchun, Jilin 130012; \\ ${ }^{4}$ Department of Anesthesiology, Hospital of Stomatology, Jilin University, Changchun, Jilin 130021, P.R. China
}

Received September 7, 2018; Accepted January 7, 2019

DOI: $10.3892 /$ ijmm.2019.4058

\begin{abstract}
By analyzing the L-glutamic acid (L-Glu)-induced apoptosis of $\mathrm{PC} 12$ cells and an $\mathrm{AlCl}_{3}$ combined with D-galactose (D-gal)-developed Alzheimer's disease (AD) mouse model, the protective effects of isoastilbin (IAB) against $\mathrm{AD}$ were systematically investigated in the present study. Pre-incubation with IAB for $3 \mathrm{~h}$ prior to treatment with $25 \mathrm{mM} \mathrm{L}$-Glu decreased cell viability and inhibited apoptosis, suppressed the accumulation of intracellular reactive oxygen species, and restored mitochondrial membrane potential in PC12 cells induced by L-Glu. In mice with AD, the reduced escape latency time in the water maze test, suppressed chronic movement in the center area of an open field test and enhanced ability to seek hidden food in a $\mathrm{Y}$ maze test indicated that abnormal behaviors had improved after 28 days of treatment with IAB. Furthermore, IAB reduced the deposition of amyloid $\beta(A \beta)$ and the expression of phosphorylated-Tau in the mouse brain and enhanced the serum levels of $A \beta$. IAB ameliorated the oxidative stress via modulating the levels of associated enzymes and improved the functioning of the
\end{abstract}

Correspondence to: Dr Hui Bi, Department of Anesthesiology, Hospital of Stomatology, Jilin University, 1500 Qinghua Road, Chaoyang, Changchun, Jilin 130021, P.R. China

E-mail: bihui0431@126.com

${ }^{*}$ Contributed equally

Abbreviations: Ach, acetylcholine; AchE, acetylcholinesterase; $\mathrm{AlCl}_{3}$, aluminum trichloride; $\mathrm{A} \beta$, amyloid $\beta ; \mathrm{Bcl}-2, \mathrm{~B}$-cell lymphoma 2; Bcl-xL, B-cell lymphoma-extra large; CAT, catalase; ChAT, choline acetyltransferase; D-gal, D-galactose; DMEM, Dulbecco's modified Eagle's medium; FBS, fetal bovine serum; GSH-Px, glutathione peroxidase; HO-1, heme oxygenase-1; HO-2, heme oxygenase-2; HS, horse serum; L-Glu, L-glutamate; MMP, mitochondrial transmembrane potential; MTT, 3-(4,5-dimethyl-2-thiazolyl)-2,5-diphenyl-2-H-tetrazolium bromide; Nrf2, NF-E2-related factor 2

Key words: isoastilbin, Alzheimer's disease, Nrf2 pathway, apoptosis, oxidative stress central cholinergic system, as indicated by an increase in acetylcholine and choline acetyltransferase concentrations. The expression levels of acetylcholine esterase were reduced in the mouse brain in response to IAB pre-treatment. In cells and brain tissue, IAB regulated the expression levels of proand anti-apoptotic proteins and enhanced the nuclear levels of NF-E2p45-related factor 2 (Nrf2); subsequently, IAB further enhanced the expression of superoxide dismutase 1, catalase, and heme oxygenase- 1 and -2 . The findings of the present study indicated that the protection of IAB against AD is at least partially associated with its antioxidation and anti-apoptotic properties.

\section{Introduction}

Alzheimer's disease (AD), due to neuron loss and synaptic degeneration, is characterized by a significant decline in cognitive function and poor prognosis, which accounts for $60-70 \%$ of all types of dementia $(1,2)$. Although the aggregated amyloid $\beta(A \beta)$ titanium and hyper-phosphorylated (p-) Tau may exhibit neurotoxicity in the development of $\mathrm{AD}$, the exact therapeutic targets have not been successfully identified due to the complex mechanism associated with the pathogenesis of this disease (3). Among the various hypotheses, the occurrence of oxidative stress and neuronal apoptosis in $\mathrm{AD}$ has been accepted. Oxidative stress, represented by the over-accumulation of reactive oxygen species (ROS), is responsible for the damage to the mitochondria, membrane lipids, and nucleic acids (4). Oxidative stress promotes $A \beta$ aggregation, which exhibits a direct toxic effect to its surrounding neurons, leading to the susceptibility of neurons to free radicals, particularly $\operatorname{ROS}(5,6)$.

As a major cellular source of ROS, mitochondria serve an important role in the pathophysiology of neurodegenerative diseases (7). The disruption of mitochondrial homeostasis caused by the high levels of ROS further leads to the over-production of ROS and other cytokines, such as cytochrome $c$, which induces the cell apoptosis program $(8,9)$. The extremely high levels of glutamate (Glu) associated with ROS accumulation, a central nervous neurotransmitter, damages neurons (10); however, during the onset of oxidative stress, the transcription factor NF-E2p45-related factor 2 (Nrf2) helps maintain cellular redox homeostasis, and supports the 
structure and functional integrity of the mitochondria (11). Furthermore, the deletion of Nrf2 can increase the intracellular levels of $\mathrm{A} \beta$ in mice with $\mathrm{AD}$ (12).

The occurrence of AD is rapidly increasing worldwide, and according to statistics, there are $>40$ million patients globally (13). As the prevention and treatment of AD has been a serious challenge, potential agents applied in clinics have failed to effectively treat patients with AD. In addition, the adverse effects of these agents have been noted, including gastrointestinal discomfort, difficulty sleeping and muscle spasms (14). Herbal compounds have been reported as a large and underappreciated source of potential agents to treat or prevent AD $(15,16)$. Evodiamine treatment resulted in the return of $\mathrm{AD}$-associated symptoms via modulating oxidative stress-mediated apoptosis in L-glutamate (L-Glu)-damaged HT22 cells, and a mouse model with $\mathrm{AlCl}_{3}$ - and D-galactose (D-gal)-induced AD (17). Polysaccharides extracted from Sparassis crispa (18) and Armillaria mellea (19) have been successfully confirmed to exert neuroprotective effects against AD. Isoastilbin (IAB), a dihydroflavonol glycoside compound (Fig. 1A), is widely distributed in Rhizoma Smilacis glabrae and Astragalus membranaceus. The majority studies of IAB have focused on its extraction and purification from herbs $(20,21)$. A study reported the antioxidative effects of IAB (22); however, astilbin, the isomer of IAB, was reported to improve the cognitive abilities of a transgenic mouse with $A D$ via regulating the protein kinase B/glycogen synthase kinase-3 $\beta$ signaling pathway (23). Based on the pharmacological activity of astilbin and the antioxidative properties of IAB, we hypothesized that IAB may exhibit neuroprotective effects against AD.

In the present study, the protective effects of IAB on restoring L-Glu-induced $\mathrm{PC} 12$ cell apoptosis, and reducing $\mathrm{AlCl}_{3}$ - and D-gal-induced AD-associated symptoms in Balb/c male mice were investigated. To the best of our knowledge, the present study is the first to report of the potential therapeutic properties of IAB against AD in an apoptotic cell model and in mice with AD-associated symptoms. The results may provide insight into the application of IAB in the adjuvant therapy of AD.

\section{Materials and methods}

Cell culture. PC12 cells (CRL-1721; American Type Culture Collection, Manassas, VA, USA) were cultured in Dulbecco's Modified Eagle's medium (DMEM; Invitrogen; Thermo Fisher Scientific, Inc., Waltham, MA, USA) containing 5\% horse serum (HS; Invitrogen; Thermo Fisher Scientific, Inc.), $10 \%$ fetal bovine serum (FBS; Invitrogen Thermo Fisher Scientific, Inc.), penicillin (100 U/ml) and streptomycin $(100 \mu \mathrm{g} / \mathrm{ml})$ (Invitrogen; Thermo Fisher Scientific, Inc.), under a humidified atmosphere containing $5 \% / 95 \% \mathrm{CO}_{2} /$ air at $37^{\circ} \mathrm{C}$.

PC12 cells underwent differentiation for $48 \mathrm{~h}$ at $37^{\circ} \mathrm{C}$ with $50 \mathrm{ng} / \mathrm{ml}$ nerve growth factor (Sigma-Aldrich; Merck KGaA, Darmstadt, Germany) dissolved in DMEM containing $1 \% \mathrm{FBS}, 1 \% \mathrm{HS}$ and $100 \mathrm{U} / \mathrm{ml}$ of penicillin/streptomycin.

Cell viability and caspase activity analysis. PC12 cells were seeded into 96 -well plates $(8,000$ cells/well/100 $\mu \mathrm{l})$, pre-treated with 10 or $30 \mu \mathrm{M}$ of IAB (purity, $\geq 95 \%$; Shanghai Yuanye
Biotechnology Co.,Ltd.,Shanghai, China) for $3 \mathrm{~h}$ at $37^{\circ} \mathrm{C}$, and then co-incubated with $25 \mathrm{mM}$ of L-Glu for another $24 \mathrm{~h}$ at $37^{\circ} \mathrm{C}$. Cell viability was detected by a 3-(4,5-dimethyl-2-thiazolyl)-2,5-diphenyl-2-H-tetrazolium bromide (MTT; cat. no. R20228, Shanghai Yuanye Biotechnology Co., Ltd., Shanghai, China) assay (19), it was used according to the manufacturer's protocols. A total of $100 \mu \mathrm{l}$ dimethyl sulfoxide was used to solubilize purple formazan crystals, then analyzing the absorbance using a microplate reader (Bio-Rad Laboratories, Inc., Hercules, CA, USA) at a wavelength of $490 \mathrm{~nm}$. The activity of caspase-3 was analyzed using a commercial kit, it was used according to the manufacturer's protocols (cat. no. G007; Nanjing Jiancheng Bioengineering Institute, Nanjing, China). The experiments were repeated eight times.

Cell apoptosis assay. PC12 cells were seeded into 6-well plates at $5 \times 10^{5}$ cells $/$ well $/ \mathrm{ml}$, and pre-treated with 10 or $30 \mu \mathrm{M}$ of IAB for $3 \mathrm{~h}$ at $37^{\circ} \mathrm{C}$, and then co-incubated with $25 \mathrm{mM}$ of $\mathrm{L}-\mathrm{Glu}$ for another $24 \mathrm{~h}$ at $37^{\circ} \mathrm{C}$. The rate of cell apoptosis was determined via the early apoptosis and late apoptosis of cells, which was analyzed by propidium iodide/Annexin $\mathrm{V}$ staining (EMD Millipore, Billerica, MA, USA) using a Muse ${ }^{\mathrm{TM}}$ Cell Analyzer flow cytometer (EMD Millipore, Billerica, MA, USA); the data was analyzed by Muse 1.4 Analysis. The experiments were repeated eight times.

ROS levels and the dissipation of mitochondrial membrane potential (MMP). PC12 cells were seeded into 6-well plates at $5 \times 10^{5}$ cells $/$ well $/ \mathrm{ml}$, and pre-treated with 10 and $30 \mu \mathrm{M}$ of IAB for $3 \mathrm{~h}$, and then co-incubated with $25 \mathrm{mM}$ of L-Glu for another $12 \mathrm{~h}$ at $37^{\circ} \mathrm{C}$. The ROS levels were analyzed by staining with 2,7-dichlorofluorescein diacetate (DCFH-DA; Sigma-Aldrich; Merck KGaA) according to a previous study (24). The alterations in MMP were analyzed with 5,5',6,6'-tetrachloro-1,1',3,3'-tetraethylbenzimidazolylcarbocyanine iodide (Sigma-Aldrich; Merck KGaA) staining as described (25). Alterations in fluorescent intensity were analyzed using a fluorescent microscope (magnification, x200; CCD camera, Axio Observer Z1; Zeiss AG, Oberkochen, Germany). The experiments were repeated eight times. Quantification of data was conducted with Image J software version 1.46 (National Institutes of Health, Bethesda, MD, USA) and expressed as the green fluorescence intensity for intracellular ROS levels, and the ratio of red to green fluorescence intensity for MMP detection.

Experimental protocol on the mouse model with AD. The present study was approved by the Animal Ethics Committee of Jilin University (no. 20170206). A total of $36 \mathrm{Balb} / \mathrm{c}$ male mice (10-weeks old, 23-35 g) were obtained from Bethune Medical College, Jilin University (Changchun, China) were housed in cages under a temperature of $23 \pm 1^{\circ} \mathrm{C}$ and humidity of 40-60\% with sufficient water and food, and under a $12 \mathrm{~h}$ light/dark cycle.

A total of 24 mice were subcutaneously injected with $120 \mathrm{mg} / \mathrm{kg}$ of D-gal and intragastrically administered $20 \mathrm{mg} / \mathrm{kg}$ of $\mathrm{AlCl}_{3}$ once per day for 56 days. At the 29 th day, the mice were randomly divided into two groups and intragastrically administered normal saline solution $(n=12)$ or $40 \mathrm{mg} / \mathrm{kg}$ of IAB $(\mathrm{n}=12)$ once daily for 28 days. The other 
A<smiles>C[C@@H]1O[C@H](OC2C(=O)c3c(O)cc(O)cc3O[C@H]2c2ccc(O)c(O)c2)[C@H](O)[C@H](O)[C@H]1O</smiles>

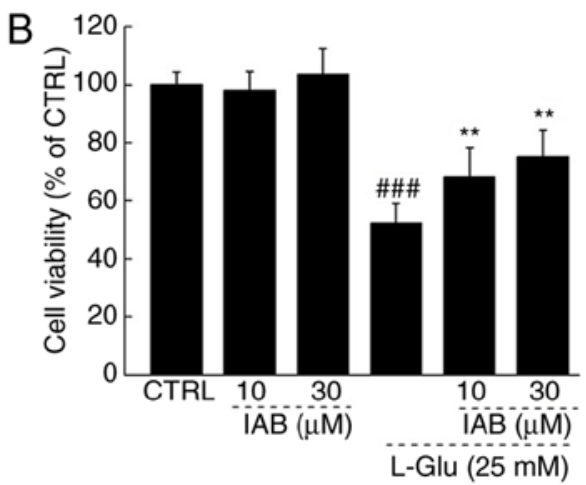

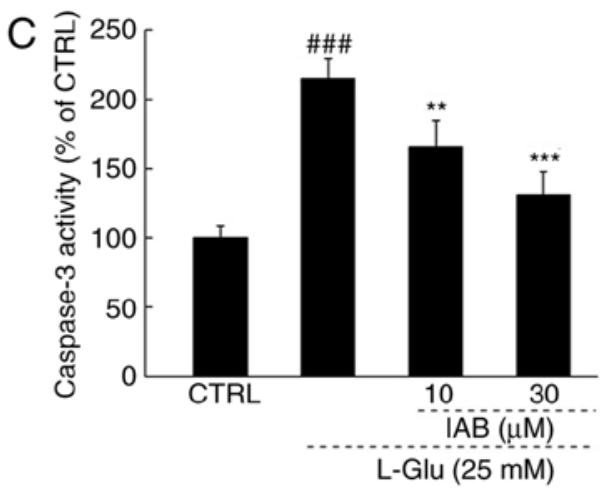

D

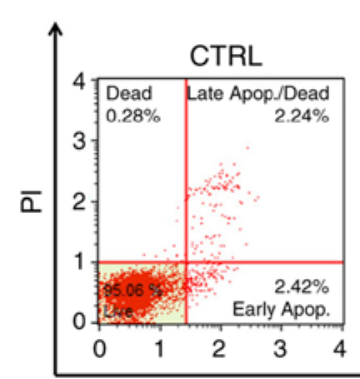

\section{L-Glu $(25 \mathrm{mM})$}

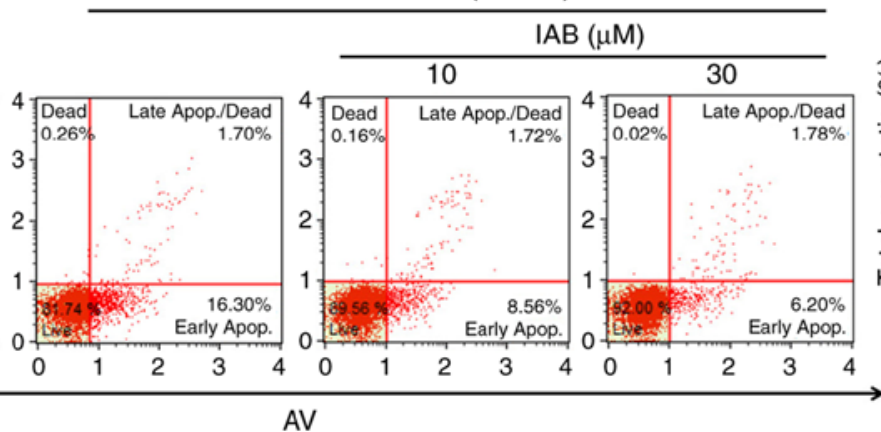

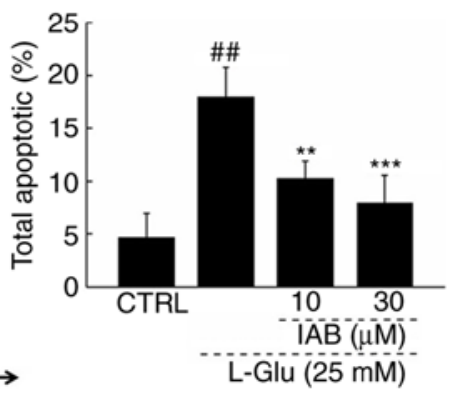

Figure 1. (A) Structural formula of IAB. (B) IAB enhanced cell viability of PC12 cells exposed to $25 \mathrm{mM}$ L-Glu for $24 \mathrm{~h}$ ( $\mathrm{n}=9$ ). (C) IAB reduced the high activity of caspase- 3 caused by L-Glu in PC12 cells (n=9). (D) IAB reduced the apoptosis rate PC12 cells exposed to L-Glu for 24 h. Data are expressed as the mean \pm standard deviation. $(\mathrm{n}=9)$. ${ }^{\# \#} \mathrm{P}<0.01$ and ${ }^{\# \#} \mathrm{P}<0.001$ vs. CTRL. ${ }^{* *} \mathrm{P}<0.01$ and ${ }^{* * * *} \mathrm{P}<0.001$ vs. L-Glu-treated cells. AV, Annexin V; CTRL, control; IAB, isoastilbin; L-Glu, L-glutamic acid; PI, propidium iodide.

12 mice were treated with normal saline solution for 56 days and served as control group. On days 54, 55 and 56, behavioral tests, including a Morris water maze test (17), an open field test (17) and the Y maze test (26), were respectively performed as previously described without modifications. At the end of the experiments, blood samples were collected from the caudal vein under anesthesia with $400 \mathrm{mg} / \mathrm{kg}(10 \%)$ chloral hydrate, and the whole brains, kidney and spleen were collected following euthanasia by injection with $150 \mathrm{mg} / \mathrm{kg}$ (1.5\%) pentobarbital, after standing at $25^{\circ} \mathrm{C}$ for $30 \mathrm{~min}$, blood samples were centrifuged at $300 \mathrm{x}$ g for $10 \mathrm{~min}$ at $25^{\circ} \mathrm{C}$ twice to obtain serum.

Levels of neurotransmitters and factors associated with oxidative stress, and A $\beta 1-42$ detection. In each group, six mice were randomly selected for the detection of biochemical indexes. The levels of ROS (cat. no. E-20634), superoxide dismutase (SOD; cat. no. E-20347), and glutathione peroxidase (GSH-Px; cat. no. E-20584) and A $\beta 1-42$ (cat. no. E-20118) in the serum and brains, and the levels of acetylcholine (Ach) (cat. no. E-20535), Ach esterase (AchE; cat. no. E-2143) and choline acetyltransferase (ChAT; cat. no. E-21422) in brains were detected by commercialized ELISA kits (Shanghai Yuanye Biological Technology Co., Ltd.).

Immunohistochemistry. Similar to a previous study, immunohistochemical analysis was conducted to analyze the levels of A $\beta 1-42$ and p-Tau (Ser404) in the brain (27). In each group, the brain tissues of six other mice were fixed with $4 \%$ formalin solution at $25^{\circ} \mathrm{C}$ for 1 week, then sliced into $5 \mu$ m-thick sections, which prepared for analysis. Briefly, after antigen retrieval via heating in $0.01 \mathrm{~mol} / 1$ citrate buffer at $98^{\circ} \mathrm{C}$, the slides were blocked in $3 \%$ hydrogen peroxide for $10 \mathrm{~min}$, and $2 \%$ goat serum for $2 \mathrm{~h}$ at room temperature, respectively. The slides were then exposed to antibodies of A $\beta 1-42$ (1:200, cat. no. bs-0877R; BIOSS, Beijing, China) and p-Tau (Ser404, 1:200, cat. no. bs-2392R; BIOSS) overnight at $4^{\circ} \mathrm{C}$, followed by incubation with a horseradish peroxidase-conjugated secondary antibody (cat. no. SH-0032; Bejing Dingguo Changsheng Biotechnology Co., Ltd., Beijing, China) at a dilution of 1:2,000 for $4 \mathrm{~h}$ at $4^{\circ} \mathrm{C}$. 3,3'-diaminobenzidine and Mayer's hematoxylin were applied for $5 \mathrm{~min}$ at $25^{\circ} \mathrm{C}$, the slides were solidified with a neutral resin and photographed by the Olympus IX73 optical microscope (Olympus Corporation, Tokyo, Japan).

Terminal deoxynucleotidyl-transferase-mediated dUTP nick end labeling (TUNEL) assay. TUNEL was applied to analyze the occurrence of apoptosis in the brain by observing the number of positive cells in the field of view (19). Following deparaffinization, the brain slides from six mice of each group were washed with PBS and covered with permeabilization reagent $(20 \mu \mathrm{g} / \mathrm{ml}$ Proteinase $\mathrm{K})$. The brain slides were incubated with TdT reaction mixture in the dark for $1 \mathrm{~h}$ at $37^{\circ} \mathrm{C}$, and then analyzed three fields per view under a Nikon Eclipse TE 2000-S fluorescence microscope (magnification, x200) Images were collected with a CCD camera.

Histological analysis. The whole brains, kidney and spleen of six mice from each group were preserved in $10 \%$ formaldehyde 
solution at $25^{\circ} \mathrm{C}$ for 1 week. Following dehydration using 100 , $95,80,70$ and 50\% ethanol and distilled water in sequence, the samples were embedded in paraffin wax and sliced into joint cavity sections of $5 \mu \mathrm{m}$ thickness. Following H\&E staining for $10 \mathrm{~min}$ at $25^{\circ} \mathrm{C}$, light microscopy was performed at x100 (for brain slides) or x200 (for kidney and splenic slides) to analyze histopathological alterations within the tissues, three fields per view were analyzed.

Western blotting. PC12 cells were seeded into 6-well plates at $5 \times 10^{5}$ cells/well $/ 1 \mathrm{ml}$, and pre-treated with 10 or $30 \mu \mathrm{M}$ of IAB for $3 \mathrm{~h}$, and then co-incubated with $25 \mathrm{mM}$ of L-Glu for another 24 h. Radioimmunoprecipitation assay buffer (Sigma-Aldrich; Merck $\mathrm{KGaA}$ ) containing $1 \%$ protease inhibitor cocktail (Sigma-Aldrich; Merck KGaA) was used to lyse the treated cells and collected brain tissues. The nuclear fractions of cells and tissue samples to determine Nrf 2 expression were obtained using a nuclear pulp separation kit (cat. no. BB-36021-2; BestBio, Shanghai, China), which was used according to the manufacturer's protocols, The protein concentration of the samples was detected by a Bicinchoninic Acid kit; $40 \mu \mathrm{g}$ of samples were separated via $12 \%$ SDS-PAGE, electrotransferred onto $0.45 \mu \mathrm{m}$ nitrocellulose membranes (Bio Basic, Inc., Toronto, Canada), and then incubated with primary antibodies including B-cell lymphoma 2 (Bcl-2; sc-70411), B-cell lymphoma-extra large (Bcl-xL; sc-8392), Bcl-2-associated X (Bax; sc-7480), cleaved caspase-3 (sc-136219), cleaved caspase-9 (sc-56076), Nrf2 (sc-722), heme oxygenase-1 (HO-1; sc-390991), HO-2 (sc-17786), superoxide dismutase 1 (SOD1; sc-271014), oxidative enzyme catalase (CAT; sc-271803) and GAPDH (sc-365062 Santa Cruz Biotechnology, Inc., Dallas, TX, SA) at dilution of $1: 1,000$ at $4^{\circ} \mathrm{C}$ overnight. The membranes were then exposed to horseradish peroxidase-conjugated secondary antibodies (sc-516102; Santa Cruz Biotechnology, Inc.) at dilution of $1: 2,000$ for $4 \mathrm{~h}$ at $4^{\circ} \mathrm{C}$. The protein blots were detected using enhanced chemiluminescence detection kits (GE Healthcare, Chicago, IL, USA), and analyzed with ImageJ software version 1.46 (National Institutes of Health, Bethesda, MD, USA).

Statistical analysis. Data were expressed as the mean \pm standard deviation for in vitro experiments and the mean \pm standard error of mean for in vivo experiments. Software SPSS 16.0 (SPSS, Inc., Chicago. IL, USA) was used to analyze the data via one-way analysis of variance, followed by a Duncan's multiple range test. $\mathrm{P}<0.05$ was considered to indicate a statistically significant difference.

\section{Results}

$I A B$ protects $P C 12$ cells against $L-G l u$-induced damage. IAB significantly improved the viability of $>30 \%$ L-Glu-damaged PC12 cells compared with cells treated with L-Glu alone $(\mathrm{P}<0.01$; Fig. 1B); however, IAB alone exhibited no significant effects on cell viability in normal PC12 cells (Fig. 1B). Compared with L-Glu-treated PC12 cells, IAB, particularly at $30 \mu \mathrm{M}$, significantly reduced caspase-3 activity by $39.1 \%$ $(\mathrm{P}<0.001$; Fig. 1C). PC12 cells exposed to $25 \mathrm{mM} \mathrm{L-Glu}$ demonstrated an apoptosis rate of $18 \%$, which decreased to $7.98 \%$ in $30 \mu \mathrm{M}$ IAB pre-treated PC12 cells ( $<<0.05$; Fig. 1D).
$I A B$ restores $R O S$-mediated MMP dissipation in $L-G l u$ damaged PC12 cells. A significant accumulation of intracellular ROS ( $\mathrm{P}<0.001$; Fig. 2A) and dissipation of MMP $(\mathrm{P}<0.001$; Fig. 2B) were observed in PC12 cells exposed to $25 \mathrm{mM}$ L-Glu for $12 \mathrm{~h}$ compared with the control. Pre-incubation with IAB significantly suppressed the over-accumulation of ROS, as indicated by the reduced green fluorescence $(\mathrm{P}<0.05$; Fig. $2 \mathrm{~A})$, and restored the dissipation of $\mathrm{MMP}$, as indicated by the enhanced red/green fluorescence $(\mathrm{P}<0.01$; Fig. $2 \mathrm{~B})$.

Significantly low expression levels of Bcl-2 $(\mathrm{P}<0.01)$ and Bcl-xL $(\mathrm{P}<0.01)$, and high expression levels of $\mathrm{Bax}(\mathrm{P}<0.001)$ and cleaved casapase-3 $(\mathrm{P}<0.001)$ and $-9(\mathrm{P}<0.001)$ in $\mathrm{PC} 12$ cells were noted after $24-\mathrm{h}$ exposure to L-Glu compared with the control (Fig. 2C). Conversely, 3-h pre-incubation with IAB significantly reversed these alterations induced by L-Glu $(\mathrm{P}<0.01$, Fig. 2C).

L-Glu exposure resulted in significant reductions in the expression of Nrf2 ( $\mathrm{P}<0.01)$, HO-1 $(\mathrm{P}<0.01), \mathrm{HO}-2(\mathrm{P}<0.05)$, SOD1 $(\mathrm{P}<0.001)$ and CAT $(\mathrm{P}<0.001)$ in $\mathrm{PC} 12$ cells compared with the control, but were strongly enhanced by IAB treatment (10 and $30 \mu \mathrm{M}$ ) after 24-h co-incubation (P<0.01; Fig. 2D).

$I A B$ alleviates the behavioral symptoms and reduced the apoptotic rate, A $\beta 1-42$ levels, and P-Tau aggregations in brains of $A D$ mice. The experimental protocol conducted with mice was presented in Fig. 3A. In addition, IAB did not exhibit adverse effects on organs, including the brain (Fig. 3B), kidneys (Fig. 3C), and spleen (Fig. 3D) of AD mice as analyzed by $\mathrm{H} \& \mathrm{E}$ staining.

The learning and memory abilities of mice with mice were analyzed by behavioral tests. In an open field test, a significant time spent in the central area with chaotic movement without purpose was observed in AD mice; however, this duration was significantly reduced in IAB-treated mice ( $\mathrm{P}<0.01$; Fig. 4A). In the Morris water maze test, compared with heathy mice, AD mice spent more time finding the platform hidden in the water and exhibited more chaotic movement. Conversely, IAB administration led to a $32.8 \%$ reduction in escape latency time $(\mathrm{P}<0.01$; Fig. 4B). In the $\mathrm{Y}$ maze test, it took AD mice nearly twice as long to find hidden food compared with the heathy mice $(\mathrm{P}<0.001$; Fig. $4 \mathrm{C})$. IAB administration led to a $30.9 \%$ reduction in the seeking time for hidden food $(\mathrm{P}<0.01$; Fig. 4C).

The apoptotic status of neurons was detected by TUNEL staining, and a number of TUNEL-positive cells were observed in the brains of the vehicle-treated AD mice, as indicated by the enhanced green fluorescence intensity (Fig. 4D). The number of TUNEL-positive cells was notably reduced following 4 weeks of treatment with IAB (Fig. 4D).

Central to pathogenesis of $\mathrm{AD}$, the levels of $\mathrm{A} \beta$, the principal constituent of neuritic plaques (28), were detected in the present study. Compared with healthy mice, significantly low serum levels of A $\beta 1-42$ and high cerebral levels of $A \beta 1-42$ were noted in the vehicle-treated AD mice compared with in healthy mice $(\mathrm{P}<0.05$; Fig. $4 \mathrm{E})$; however, IAB administration for 4 weeks resulted in a $29.8 \%$ increase in the serum levels of $\mathrm{A} \beta 1-42(\mathrm{P}<0.05)$ and a $22.9 \%$ reduction in the cerebral levels of $\mathrm{A} \beta 1-42(\mathrm{P}<0.05$; Fig. $4 \mathrm{E})$. Immunohistochemical analysis further confirmed that the suppressive activities of IAB on $\mathrm{A} \beta 1-42$ in the mouse brains resulted in fewer neuritic plaques 

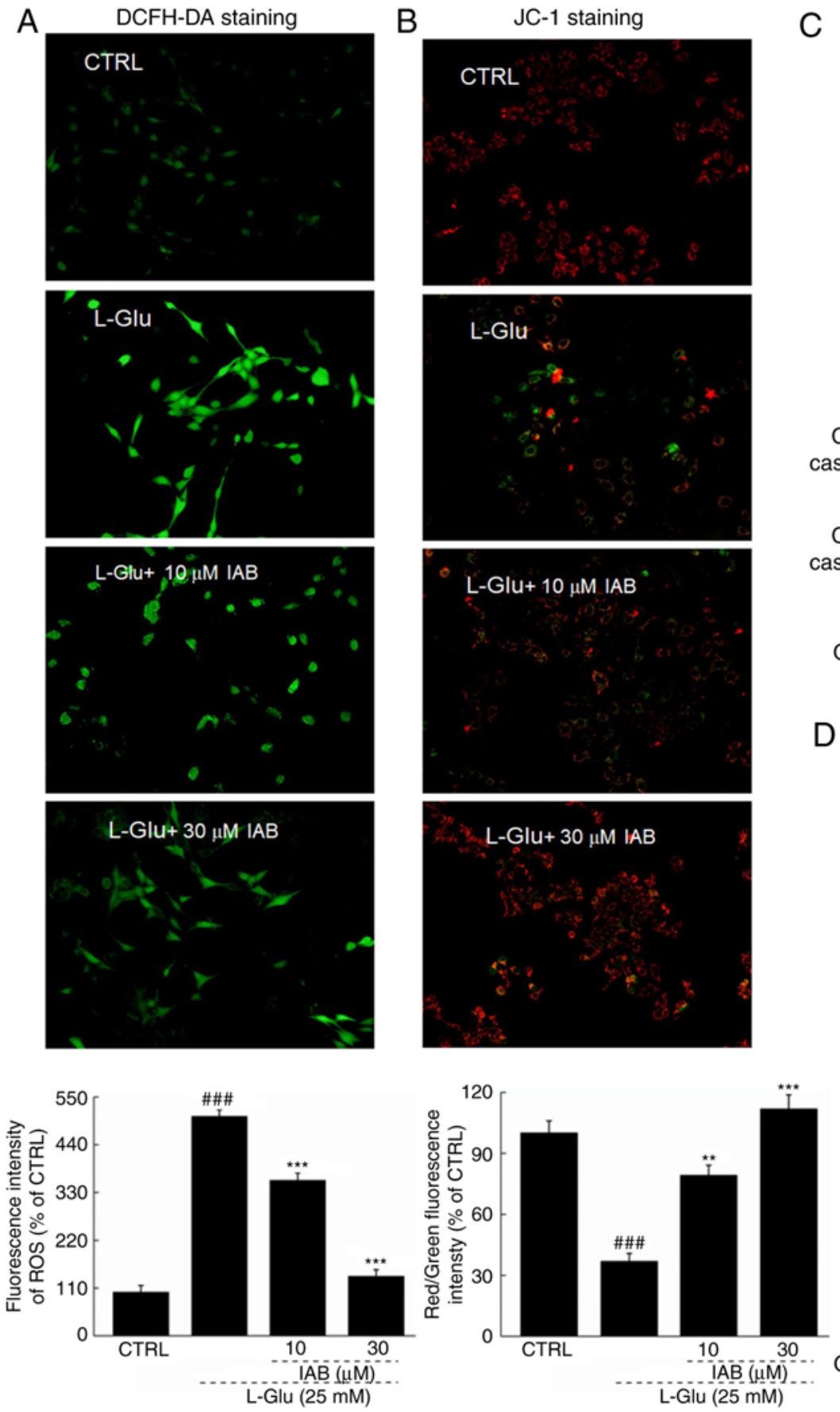

C

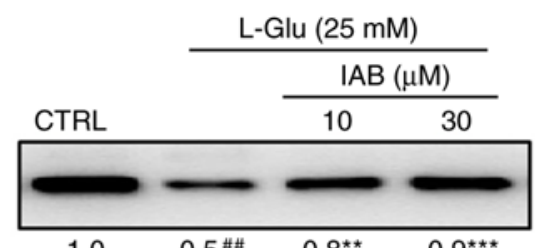

Bcl-xL

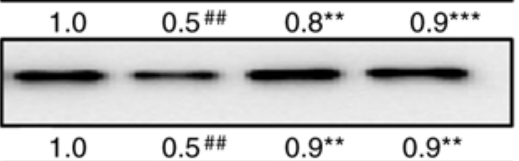

Bax

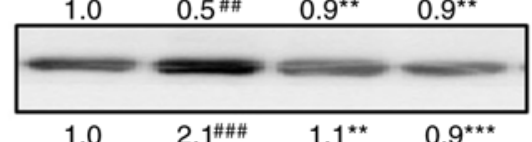

Cleaved

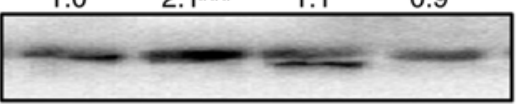

$\begin{array}{llll}1.0 & 1.8^{\# \# \#} & 1.3^{\star \star} & 0.8^{\star \star \star}\end{array}$

Cleaved caspase-9

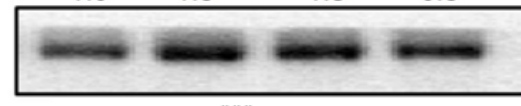

GAPDH

$\begin{array}{llll}1.0 & 2.2^{\# \# \#} \quad 2.1 & 1.7^{\star \star}\end{array}$

D

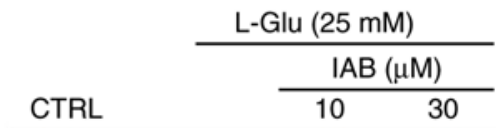

Nrf2

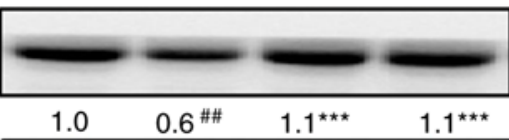

HO-1

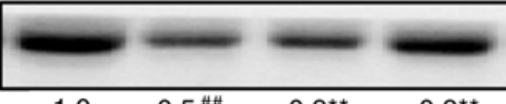

$\mathrm{HO}-2$

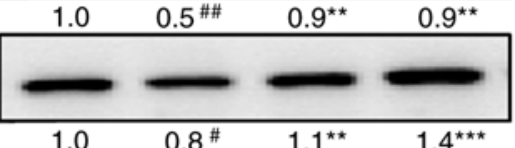

SOD1

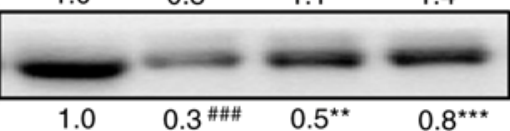

CAT

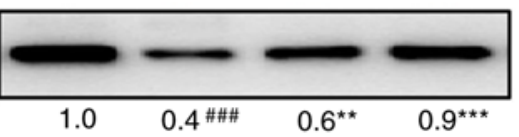

GAPDH

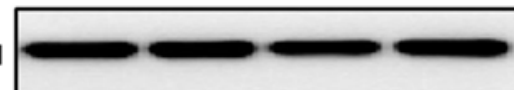

Figure 2. IAB ameliorates L-Glu-induced mitochondrial apoptosis in PC12 cells via regulation the Nrf2 pathway. (A) IAB suppressed the over-accumulation of ROS in PC12 cells exposed to L-Glu for $12 \mathrm{~h}(\mathrm{n}=9)$. (B) IAB restored L-Glu-induced mitochondrial membrane potential dissipation after 12-h co-incubation $(\mathrm{n}=9)$. Data are expressed as mean \pm standard deviation. $(\mathrm{n}=9)$. (C) IAB enhanced the expression levels of $\mathrm{Bcl}-2$ and $\mathrm{Bcl}-\mathrm{xL}$, and reduced the expression levels of Bax, cleaved caspases-3 and -9 in PC12 cells exposed to L-Glu for $24 \mathrm{~h}$ (n=6). (D) IAB strongly enhanced the expression levels of Nrf2, HO-1, HO-2, SOD1 and CAT in PC12 cells exposed to L-Glu for $24 \mathrm{~h}(\mathrm{n}=6)$. Quantification data was normalized by GAPDH. The mean fold of band intensity compared with CTRL group was presented respectively. ${ }^{\#} \mathrm{P}<0.05$, ${ }^{\# \#} \mathrm{P}<0.01$ and ${ }^{\# \#} \mathrm{P}<0.001$ vs. CTRL. ${ }^{* *} \mathrm{P}<0.01$ and ${ }^{* * * *} \mathrm{P}<0.001$ vs. L-Glu-treated cells. Bcl-2, B-cell lymphoma-2; Bax, Bcl-2-associated X; Bcl-xL, Bcl-extra large; CAT catalase; CTRL, control; HO, heme oxygenase; IAB, isoastilbin; L-Glu, L-glutamic acid; Nrf2, NF-E2p45-related factor 2; ROS, reactive oxygen species; SOD, superoxide dismutase.

in IAB-treated mice than in AD mice (Fig. 4F). Furthermore, the expression levels of $\mathrm{p}$-Tau were notably enhanced in the brains of vehicle-treated AD mice, but were significantly reduced upon treatment with IAB (Fig. 4G).

$I A B$ regulates the levels of cholinergic neurotransmitters in mice with $A D$. The dysregulated levels of cholinergic neurotransmitters is responsible for the characteristic memory impairment associated with AD (29). Significant reductions in the levels of Ach $(\mathrm{P}<0.05)$ and ChAT $(\mathrm{P}<0.01)$, and increased levels of AchE $(\mathrm{P}<0.01)$ were observed in the brains of the vehicle-treated $\mathrm{AD}$ mice compared with the control (Fig. 5). After 4 weeks of treatment with IAB, a 24.9 and $25.3 \%$ increase in the cerebral levels of Ach $(\mathrm{P}<0.05$; Fig. 5A) and ChAT $(\mathrm{P}<0.05$; Fig. 5C) were observed, respectively, and a $30.6 \%$ reduction in the cerebral levels of AchE were detected 
A

$120 \mathrm{mg} / \mathrm{kg}$ of D-gal (i.p.) \& $20 \mathrm{mg} / \mathrm{kg}$ of $\mathrm{AlCl}_{3}$ (i.g.)
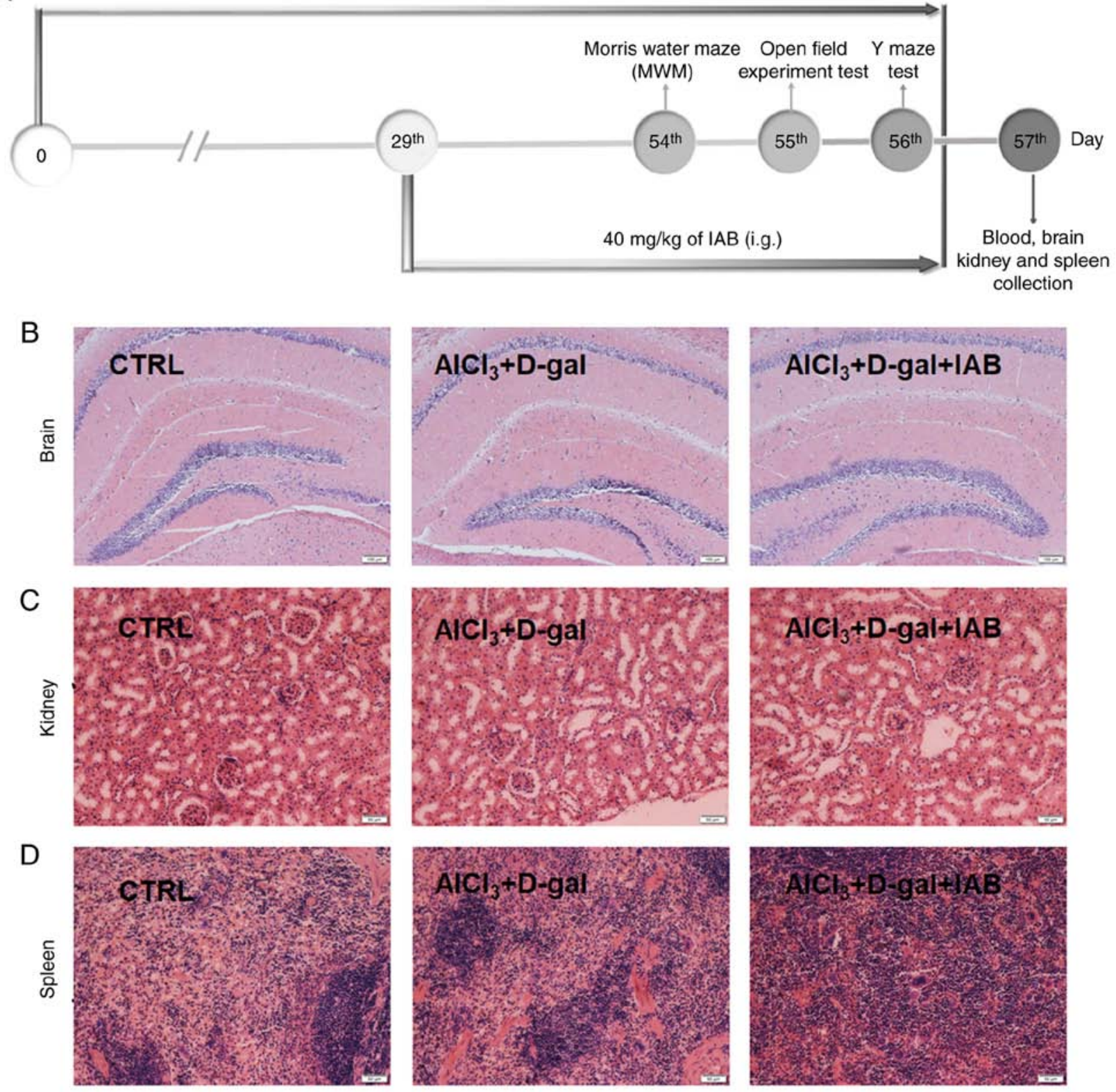

Figure 3. (A) Schematic of animal experiments. No notable pathological alterations were noted in the (B) brain (magnification, $\mathrm{x} 100$; scale bar, $100 \mu \mathrm{m}$ ), (C) kidney (magnification, x200; scale bar, $50 \mu \mathrm{m}$ ) and (D) spleen (magnification, x200; scale bar, $50 \mu \mathrm{m}$ ) among all experimental mice ( $\mathrm{n}=6$ ). CTRL, control; D-gal, D-galactose; IAB, isoastilbin.

$(\mathrm{P}<0.05$; Fig. 5B). These findings suggests that may IAB improve cholinergic dysfunction.

$I A B$ regulates $N r f 2$ signaling to modulate the levels of pro- and antioxidative factors in mice with $A D$. The brain is sensitive to oxidative stress; consequently, the over-accumulation of ROS may affect the expression of $\beta$-amyloid precursor protein (APP) and mitochondrial DNA, which further leads to neuronal apoptosis (30). Compared with in healthy mice, significantly higher levels of ROS, and notably lower levels of SOD and GSH-Px were detected in the serum and brains of vehicle-treated $A D$ mice $(\mathrm{P}<0.05$; Fig. $6 \mathrm{~A}-\mathrm{F})$. In the serum of $\mathrm{AD}$ mice, IAB significantly reduced ROS levels by $17.9 \%$ ( $\mathrm{P}<0.05$; Fig. 6A), and enhanced the levels of SOD by $21.4 \%$ $(\mathrm{P}<0.05$; Fig. 6B) and GSH-Px by $71.6 \%$ (P<0.01; Fig. 6C). In the brains of mice with $\mathrm{AD}$, IAB significantly reduced ROS levels by $29.7 \%$ ( $\mathrm{P}<0.01$; Fig. 6D), and enhanced the levels of SOD by $94.2 \%(\mathrm{P}<0.001$; Fig. $6 \mathrm{E})$ and GSH-Px by $80.7 \%$ $(\mathrm{P}<0.001$; Fig. 6F).

In the brains of $\mathrm{AD}$ mice, notably increased expression levels of pro-apoptotic proteins, including $\mathrm{Bax}(\mathrm{P}<0.001$; Fig. 6G) and cleaved caspases-3 $(\mathrm{P}<0.01$; Fig. 6G) and -9 $(\mathrm{P}<0.001$; Fig. 6G), and the low levels of anti-apoptotic proteins, such as Bcl-2 $(\mathrm{P}<0.01)$ and $\mathrm{Bcl}-\mathrm{xL}(\mathrm{P}<0.01)$, were observed (Fig. 6G). The expression levels were similar to the control after 4 weeks of treatment with IAB $(\mathrm{P}<0.01$; Fig. $6 \mathrm{G})$, all were strongly improved to a healthy standard after four-week IAB administration (Fig. 6G). Additionally, the notably reduced levels of proteins associated with antioxidation, including Nrf2 $(\mathrm{P}<0.001)$, HO-1 $(\mathrm{P}<0.01)$, HO-2 $(\mathrm{P}<0.01)$, SOD1 $(\mathrm{P}<0.001)$ and CAT $(\mathrm{P}<0.001)$, were detected in the brains of mice with $\mathrm{AD}$ (Fig. 6G). On the contrary, the suppressed expression of these 

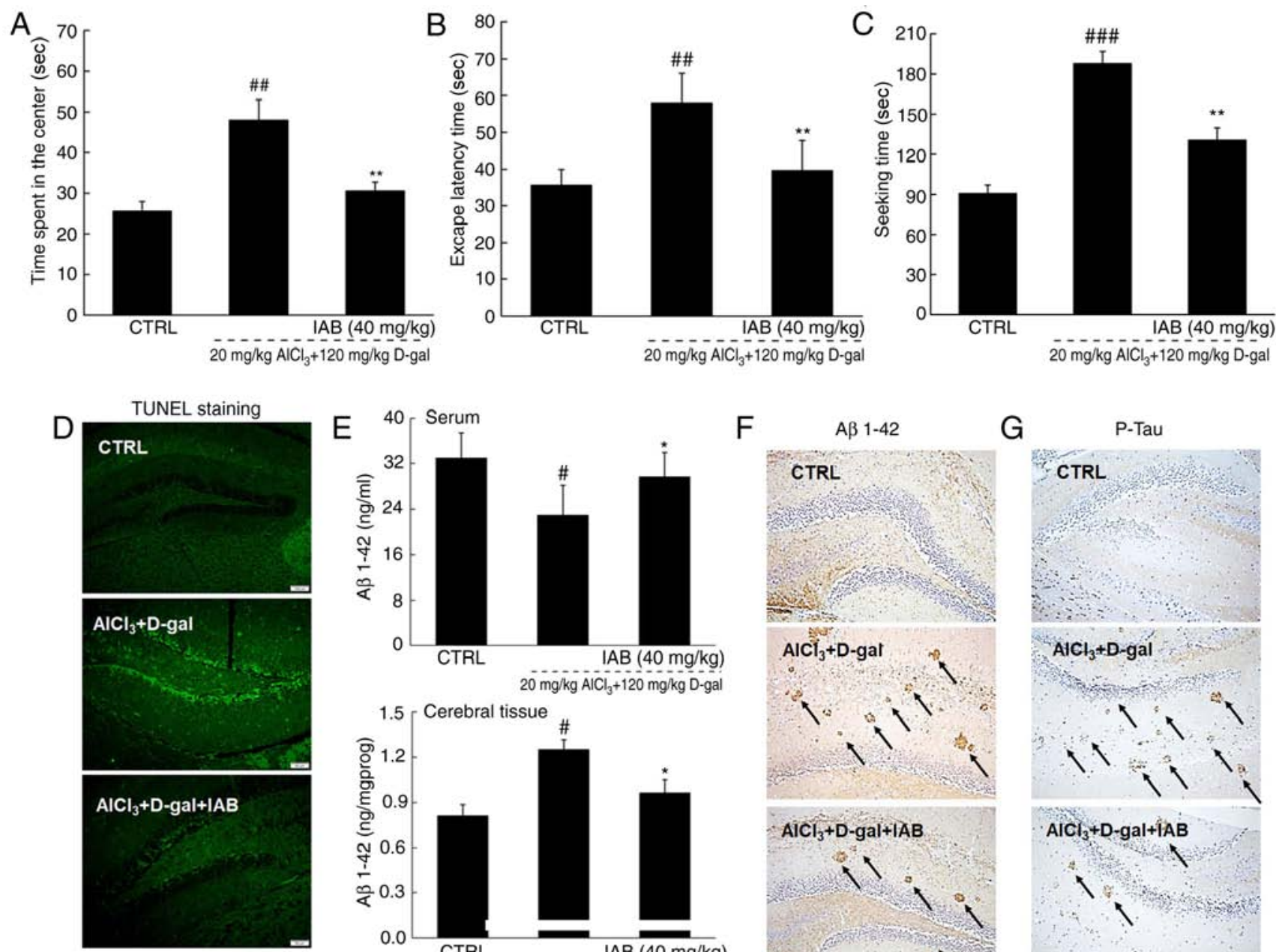

F

A $1-42$

G
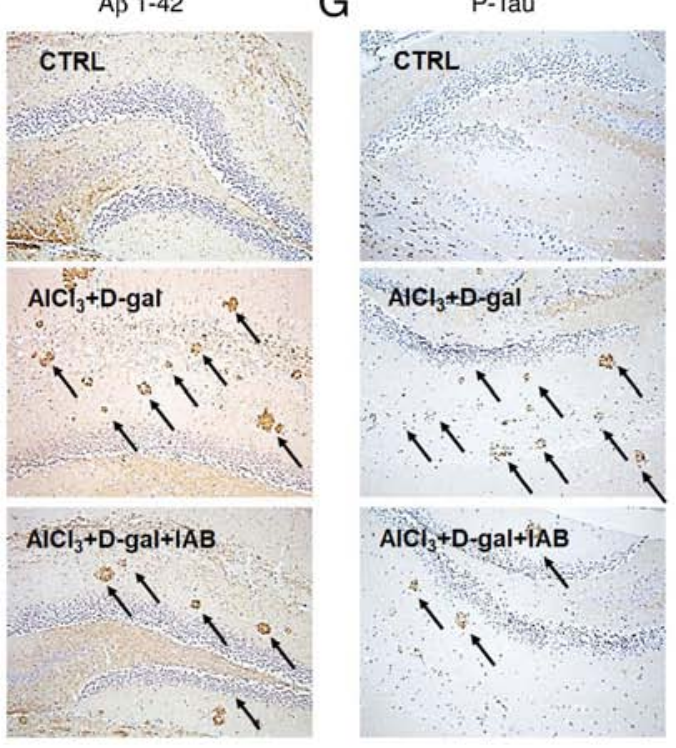

Figure 4. IAB improves AD-like behaviors, and inhibits $\mathrm{A} \beta 1-42$ deposition and p-Tau accumulation in mice with D-gal and $\mathrm{AlCl}_{3}$-induced $\mathrm{AD}$. Compared with vehicle-treated $\mathrm{AD}$ mice, 28-day administration of IAB reduced (A) the escape latency time in the Morris water maze test, (B) the time spent in the central area in open field test and $(C)$ the time to seek hidden food in the $\mathrm{Y}$ maze test. Data are expressed as mean \pm standard error of the mean. $(\mathrm{n}=12)$. ${ }^{\# \#} \mathrm{P}<0.01$ and ${ }^{\# \# \# P} \mathrm{P}<0.001$ vs. CTRL, ${ }^{* *} \mathrm{P}<0.01$ vs. vehicle-treated AD mice. (D) IAB suppressed the apoptosis in the brain of AD mice (n=12). (E) IAB enhanced the serum levels of $A \beta 1-42$, and reduced the cerebral levels of $A \beta 1-42$ in $A D$ mice as detected via ELISA. Data are expressed as mean \pm standard error of the mean. (n=6). ${ }^{\#} \mathrm{P}<0.05$ vs. CTRL, ${ }^{\prime} \mathrm{P}<0.05$ vs. vehicle-treated $\mathrm{AD}$ mice. (F) A $\beta$ deposits in the brain of $\mathrm{AD}$ mice were significantly decreased by IAB detecting by immunohistochemistry. Magnification, $x 200(n=6)$. Arrows show A $\beta$ deposit. (G) Increased expression of $\mathrm{p}$-Tau in the brain of AD mice was significantly suppressed by IAB as detected by immunohistochemistry. Magnification, $x 200(n=6)$. Arrows show neurofibrillary tangle induced by P-Tau. A $\beta$, amyloid $\beta$; AD, Alzheimer's disease; CTRL, control; D-gal, D-galactose; IAB, isoastilbin.

proteins induced by the occurrence of oxidative stress within the AD process markedly recovered following IAB treatment, which resulted in $>50 \%$ upregulation $(\mathrm{P}<0.01$; Fig. $6 \mathrm{G})$.

\section{Discussion}

Apoptotic neurons have been detected in patients with AD (31). Based on our preliminary experiments, the neuroprotective effects of numerous natural compounds including IAB, astilbin and curculigoside were screened in L-Glu-damaged PC12 cells, and the results revealed that IAB exhibited the best protective effects than the other compounds. In the present study, IAB significantly reduced L-Glu-induced apoptosis of PC12 cells and apoptosis in the brains of mice with $\mathrm{AD}$, which was induced with $\mathrm{AlCl}_{3}$ and D-gal. The notably high levels of Glu in brains is responsible for the occurrence of oxidative stress, as indicated by the over-accumulation of ROS, which opens mitochondrial permeability transition pores, resulting in the further dissipation of MMP (32). As of the feedback loop between the increased production of ROS and mitochondrial dysfunction, pro-apoptotic cytokines, such as cytochrome $c$ are released from the mitochondria and bind to apoptotic protease activating factor $1(33,34)$. This complex recruits caspase-9 to activate caspase-3 via proteolytic cleavage $(35,36)$. Consequently, caspase-3 is the executor of the apoptotic program (37). In L-Glu-damaged PC12 cells and the brains of mice with AD, IAB significantly reduced the expression of caspase- -9 and -3 , and regulated the expression of Bcl-2 family members, which suggests the inhibition of mitochondria-mediated apoptosis. Bcl-2 family members, which are located in the membrane of mitochondria, affect mitochondrial apoptosis (38). The ratio of pro- and anti-apoptotic members can directly reflect the function of mitochondria $(39,40)$. Upregulated Bax levels accelerate apoptosis by permeabilizing mitochondria (41). Conversely, the enhanced expression of Bcl-2 and Bcl-xL may help improve MMP (39). 

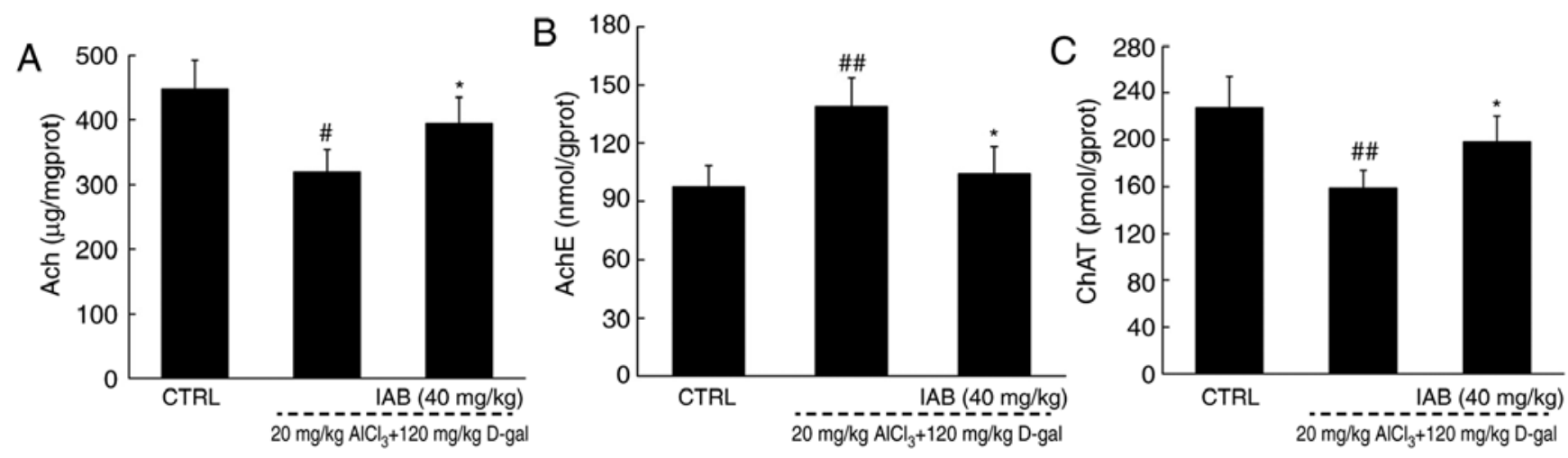

Figure 5. IAB regulates the cholinergic system in mice with $\mathrm{AD}$. Compared with vehicle-treated AD mice, 28-day administration of IAB dysregulated the levels of (A) Ach, (B) AchE and (C) ChAT in the brains of mice with AD. Data are expressed as mean \pm standard error of the mean $(\mathrm{n}=6) .{ }^{\#} \mathrm{P}<0.05$ and ${ }^{\# \#} \mathrm{P}<0.01$ vs. CTRL mice, "P<0.05 vs. vehicle-treated AD mice. Ach, acetylcholine; AchE, acetylcholinesterase; AD, Alzheimer's disease; ChAT, choline acetyltransferase; D-gal, D-galactose; IAB, isoastilbin.
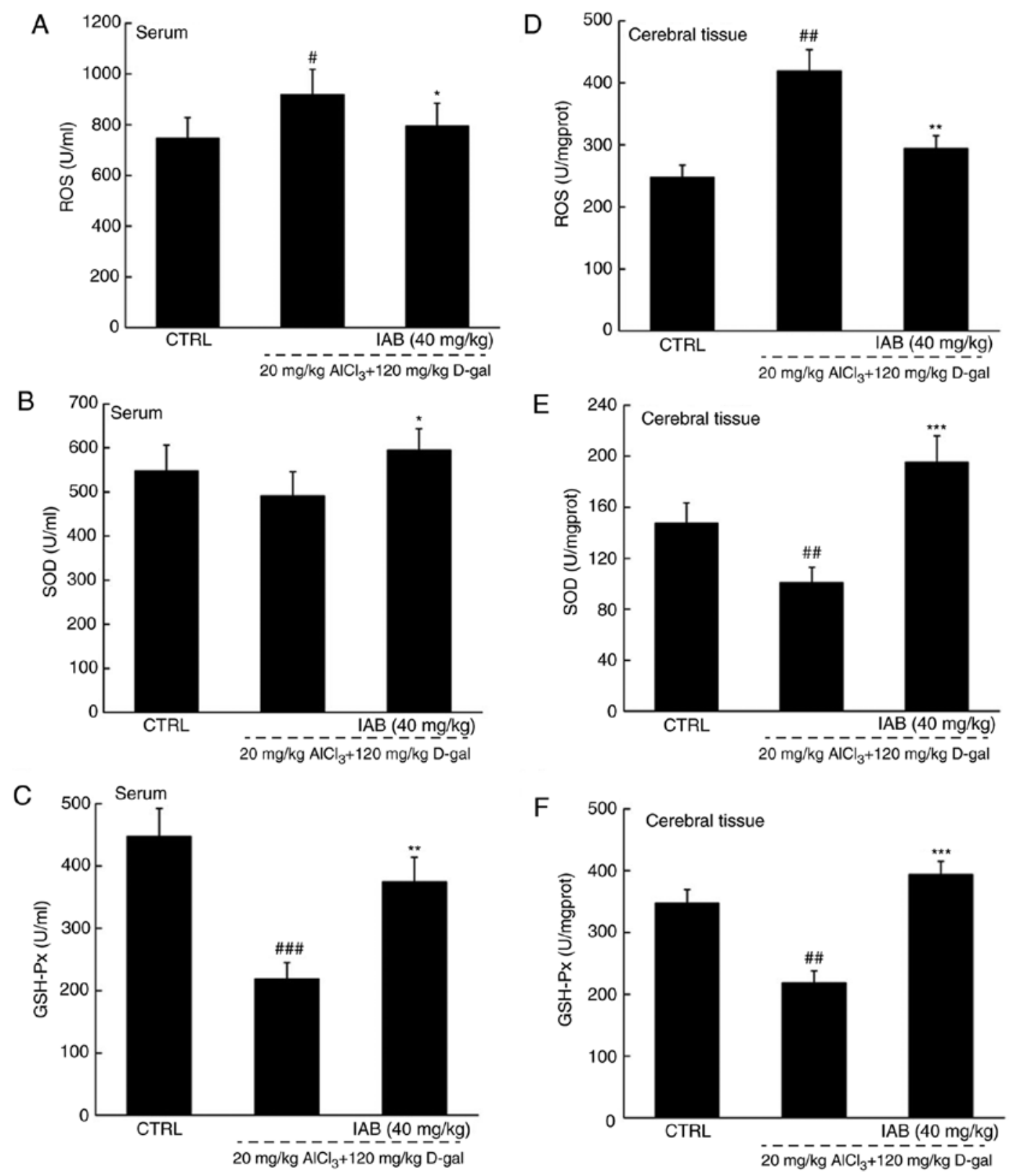

Figure 6. IAB relieves oxidative stress in mice with $\mathrm{AD}$ via the regulation of the Nrf2 pathway. Compared with vehicle-treated AD mice, 28-day administration of IAB reduced the levels of (A and D) ROS, and enhanced the levels of (B and E) SOD and (C and F) GSH-Px in the serum and whole brains of mice with AD. Data are expressed as mean \pm standard error of the mean $(n=6)$. 
G
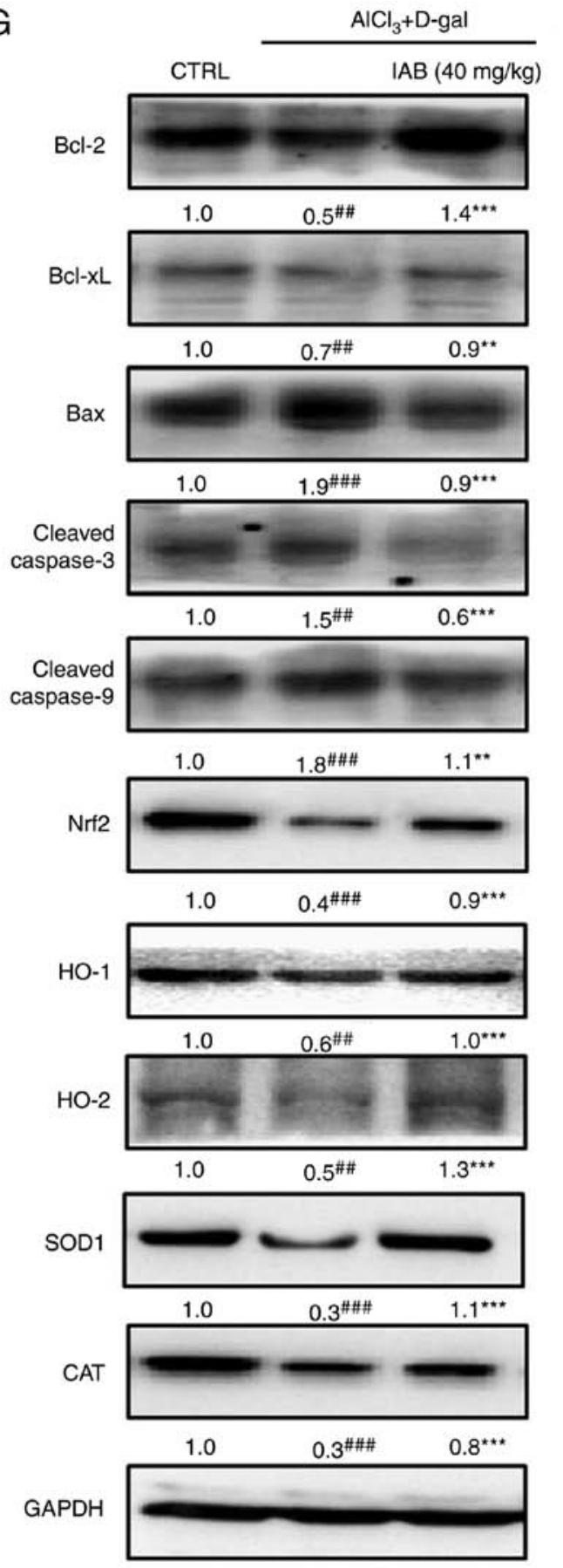

Figure 6. Continued. (G) IAB regulated the expression of proteins associated apoptosis and oxidative stress in the brains of $\mathrm{AD}$ mice $(\mathrm{n}=6)$. Quantification data was normalized by GAPDH. The mean fold of band intensity compared with CTRL group was presented respectively. ${ }^{\#} \mathrm{P}<0.05,{ }^{\# \#} \mathrm{P}<0.01$ and ${ }^{\# \# \#} \mathrm{P}<0.001$ vs. CTRL mice. ${ }^{*} \mathrm{P}<0.05,{ }^{* *} \mathrm{P}<0.01$ and ${ }^{* * *} \mathrm{P}<0.001$ vs. vehicle-treated $\mathrm{AD}$ mice. $\mathrm{AD}$, Alzheimer's disease; Bcl-2, B-cell lymphoma-2; Bax, Bcl-2-associated X; Bcl-xL, Bcl-extra large; CAT catalase; CTRL, control; D-gal, D-galactose; GSH-Px, glutathione peroxidase; HO, heme oxygenase; IAB, isoastilbin; L-Glu, L-glutamic acid; Nrf2, NF-E2p45-related factor 2; ROS, reactive oxygen species; SOD, superoxide dismutase.

The transcription factor Nrf2 supports the structural and functional integrity of the mitochondria (42). In response to apoptosis, Nrf-2 becomes activated and released, and binds to corresponding proteins in the nucleus to form dimers (43). This results in the activation and transactivation of HO-1 and HO-2, which consequently leads to the enhanced activities of SOD and CAT $(44,45)$. As an antioxidant enzyme, SOD1 helps suppress the toxicity of superoxide radicals (46). HO-1 and -2 can be activated by Nrf 2 under conditions of oxidative stress, which provides powerful protection against oxidative injury (47). These cascade activations may be associated with the etiology of $\mathrm{AD}$ and provide the possibility for screening therapeutic targets; we speculate that IAB enhanced cascade activation within the Nrf2 pathway, which may be involved in the neuroprotection of IAB against AD.

During the development of AD in mice, long-term D-gal and $\mathrm{AlCl}_{3}$ administration leads to the accumulation of ROS and damage to polyunsaturated fatty acids contained in the brain, which is responsible for the appearance of AD-like symptoms, including cognitive disorders and dysmnesia $(48,49)$. During this process, the aggregation of $A \beta$ can be observed, which induces cascade reactions, such as mitochondrial dysfunction $(40,50)$, and triggers the pathological Tau, which in turn contributes to the formation of neurofibrillary tangles (27). However, $A \beta$ plaque deposition in the brain disturbs the anti- and pro-oxidation equilibrium and enhances ROS production in particular (51). Additionally, IAB not only suppressed the abnormal accumulation of $A \beta 1-42$ and p-Tau in the mouse brain, but also regulated the redox system via modulating the expression levels including Bcl-2, Bcl-xL, Bax, cleaved caspase- 9 and -3 and the activation of the Nrf2 pathway in mice with AD. Combined with the occurrence of oxidative stress, oxidized biomolecules and ROS accumulate in cells, which consequently promotes amyloidogenic APP processing and A $\beta$ overproduction (52). Under these conditions, Nrf2 activates a series of kinases, including SOD1, CAT, and HO-1 and -2 , which in eliminate the accumulated ROS (53). SOD and GSH-Px, which are representative endogenous antioxidants, have been recognized as the first-line drugs to defend against oxidative damage (54). Combined with the suppressed ROS generation, the cerebral deposition of $A \beta$ can be removed from brains, as evidenced by enhanced peripheral levels (55). As of the activated Nrf2, the inhibited deposition of $A \beta$ leads to the fragmentation of $\mathrm{p}$-Tau aggregation $(56,57)$. These data suggest that the ability of IAB to improve the cognitive performance of mice with AD may be associated with Nrf2-mediated oxidative stress.

The loss of cholinergic neurotransmission in cerebral areas is responsible for the cognitive deterioration in patients with $\mathrm{AD}$ (58). Abnormally low levels of Ach and ChAT, and upregulated levels of AchE were noted in the brains of mice with $\mathrm{AD}$ in the present study, all of which were notably restored by IAB. Ach, controlled by the terminating enzyme AchE and the synthesizing enzyme ChAT (59), stimulates cholinergic function, and contributes to the storage and recovery of long-term memory (60); due to increased AchE and decreased ChAT, cognitive function gradually decreases (29). Under oxidative stress, increased levels of AchE promote the formation and deposition of $A \beta$ plaques (61), which severely damages the cholinergic system (62). Based on the findings of the present study, the protective role of IAB in the cholinergic system against $\mathrm{AD}$ were proposed; however, the association between the cholinergic transmitter and Nrf2-mediated oxidative stress was not clearly elaborated. This will be investigated in our ongoing research.

In conclusion, L-Glu-induced apoptosis of PC12 cells, and $\mathrm{AlCl}_{3}$ - and D-gal-induced $\mathrm{AD}$ mice models were generated in 
the present study. To the best of our knowledge, the present study is the first to report of the neuroprotection of IAB, and this property, may be, at least partly, associated with the regulation of IAB on Nrf2-mediated oxidative stress. The results provide insight for further study into the protective effects of IAB and its possibility of clinical application in $\mathrm{AD}$ in the future.

\section{Acknowledgements}

Not applicable.

\section{Funding}

The present study was supported by the Special Projects of Cooperation among Jilin University and Jilin (China; grant no. SXGJSF2017-1) and the Science Foundation in Jilin of China (China; grant no. 20180101098JC).

\section{Availability of data and materials}

All data generated and analyzed during the present study are included in this published article.

\section{Authors' contributions}

HB made substantial contributions to the design of the present study. HY, BY, QC and CW performed the experiments and analyzed the data; HB, HY and BY wrote the paper, and HB revised the paper.

\section{Ethics approval and consent to participate}

The experimental animal protocol was approved by the Animal Ethics Committee of Jilin University (no. 20170206).

\section{Patient consent for publication}

Not applicable.

\section{Competing interests}

The authors declare that they have no competing interests.

\section{References}

1. Cheignon C, Tomas M, Bonnefont-Rousselot D, Faller P, Hureau $\mathrm{C}$ and Collin F: Oxidative stress and the amyloid beta peptide in Alzheimer's disease. Redox Biol 14: 450-464, 2018.

2. Coimbra JRM, Marques DFF, Baptista SJ, Pereira CMF, Moreira PI, Dinis TCP, Santos AE and Salvador JAR: Highlights in BACE1 Inhibitors for Alzheimer's disease treatment. Front Chem 6: 178, 2018.

3. Rosello A, Warnes G and Meier UC: Cell death pathways and autophagy in the central nervous system and its involvement in neurodegeneration, immunity and central nervous system infection: To die or not to die-that is the question. Clin Exp Immunol 168 : 52-57, 2012.

4. Angelova PR and Abramov AY: Role of mitochondrial ROS in the brain: From physiology to neurodegeneration. FEBS Lett 592: 692-702, 2018.

5. de Oliveira RB, Gravina FS, Lim R, Brichta AM, Callister RJ and van Helden DF: Heterogeneous responses to antioxidants in noradrenergic neurons of the Locus coeruleus indicate differing susceptibility to free radical content. Oxid Med Cell Longev 2012: 820285, 2012.
6. Daulatzai MA: Cerebral hypoperfusion and glucose hypometabolism: Key pathophysiological modulators promote neurodegeneration, cognitive impairment, and Alzheimer's disease. J Neurosci Res 95: 943-972, 2017.

7. Nesi G, Sestito S, Digiacomo M and Rapposelli S: Oxidative stress, mitochondrial abnormalities and proteins deposition: Multitarget approaches in Alzheimer's disease. Curr Top Med Chemy 17: 3062-3079, 2017.

8. Tyagi N, Ovechkin AV, Lominadze D, Moshal KS and Tyagi SC: Mitochondrial mechanism of microvascular endothelial cells apoptosis in hyperhomocysteinemia. J Cell Biochem 98: $1150-1162,2006$

9. Liu X, Wang J, Lu C, Zhu C, Qian B, Li Z, Liu C, Shao J and Yan J: The role of lysosomes in BDE 47-mediated activation of mitochondrial apoptotic pathway in HepG2 cells. Chemosphere 124: 10-21, 2015.

10. Luo P, Fei F, Zhang L, Qu Y and Fei Z: The role of glutamate receptors in traumatic brain injury: Implications for postsynaptic density in pathophysiology. Brain Res Bull 85: 313-320, 2011

11. Dinkova-Kostova AT and Abramov AY: The emerging role of Nrf2 in mitochondrial function. Free Radic Biol Med 88: 179-188, 2015.

12. Joshi G, Gan KA, Johnson DA and Johnson JA: Increased Alzheimer's disease-like pathology in the APP/ PS1 $\triangle \mathrm{E} 9$ mouse model lacking Nrf2 through modulation of autophagy. Neurobiol Aging 36: 664-679, 2015.

13. McDade E and Bateman RJ: Stop alzheimer's before it starts. Nature 547: 153-155, 2017.

14. Querfurth HW and LaFerla FM: Alzheimer's Disease. N Engl J Med 362: 329-344, 2010.

15. Jesky R and Hailong C: Are herbal compounds the next frontier for alleviating learning and memory impairments? An integrative look at memory, dementia and the promising therapeutics of traditional Chinese medicines. Phytother Res 25: 1105-1118, 2011.

16. Man SC, Chan KW, Lu JH, Durairajan SS, Liu LF and Li M: Systematic review on the efficacy and safety of herbal medicines for vascular dementia. Evid Based Complement Alternat Med 2012: 426215, 2012.

17. Zhang Y, Wang J, Wang C, Li Z, Liu X, Zhang J, Lu J and Wang D: Pharmacological basis for the use of evodiamine in alzheimer's disease: Antioxidation and antiapoptosis. Int J Mol Sci 19: pii: E1527, 2018

18. Hu S, Wang D, Zhang J, Du M, Cheng Y, Liu Y, Zhang N, Wang D and Wu Y: Mitochondria related pathway is essential for polysaccharides purified from Sparassis crispa mediated neuro-protection against glutamate-induced toxicity in differentiated PC12 cells. Int J Mol Sci 17: pii: E133, 2016.

19. An S, Lu W, Zhang Y, Yuan Q and Wang D: Pharmacological basis for use of Armillaria mellea polysaccharides in Alzheimer's disease: Antiapoptosis and antioxidation. Oxid Med Cell Longev 2017: 4184562, 2017.

20. Du Q, Li L and Jerz G: Purification of astilbin and isoastilbin in the extract of Smilax glabra rhizome by high-speed counter-current chromatography. J Chromatogr A 1077: 98-101, 2005.

21. Zhou X, Xu Q, Li JX and Chen T: Structural revision of two flavanonol glycosides from Smilax glabra. Planta Med 75: 654-655, 2009.

22. Lu CL, Zhu W, Wang M, Xu XJ and Lu CJ: Antioxidant and anti-inflammatory activities of phenolic-enriched extracts of Smilax glabra. Evid Based Complement Alternat Med 2014: 910438, 2014

23. Wang D, Li S, Chen J, Liu L and Zhu X: The effects of astilbin on cognitive impairments in a transgenic mouse model of Alzheimer's disease. Cell Mol Neurobiol 37: 695-706, 2017.

24. Zhang X, Chen Y, Cai G, Li X and Wang D: Carnosic acid induces apoptosis of hepatocellular carcinoma cells via ROS-mediated mitochondrial pathway. Chem Biol Interact 277: 91-100, 2017.

25. Li Z, Chen X, Lu W, Zhang S, Guan X, Li Z and Wang D: Anti-oxidative stress activity is essential for Amanita caesarea mediated neuroprotection on glutamate-induced apoptotic HT22 cells and an Alzheimer's disease mouse model. Int J Mol Sci 18: pii: E1623. 2017.

26. Parikh A, Kathawala K, Li J, Chen C, Shan Z, Cao X, Wang YJ, Garg S and Zhou XF: Self-nanomicellizing solid dispersion of edaravone: Part II: In vivo assessment of efficacy against behavior deficits and safety in Alzheimer's disease model. Drug Des Devel Ther 12: 2111-2128, 2018.

27. Zhao JM, Li L, Chen L, Shi Y, Li YW, Shang HX, Wu LY, Weng ZJ, Bao CH and Wu HG: Comparison of the analgesic effects between electro-acupuncture and moxibustion with visceral hypersensitivity rats in irritable bowel syndrome. World J Gastroenterol 23: 2928-2939, 2017. 
28. Chun KA: Beta-amyloid imaging in dementia. Yeungnam Univ J Med 35: 1-6, 2018.

29. Yamini $P$, Ray RS and Chopra $K$ : Vitamin $D_{3}$ attenuates cognitive deficits and neuroinflammatory responses in ICV-STZ induced sporadic Alzheimer's disease. Inflammopharmacology 26: 39-55, 2018.

30. Tönnies E and Trushina E: Oxidative stress, synaptic dysfunction, and Alzheimer's disease. J Alzheimers Dis 57: 1105-1121, 2017.

31. Koh CH, Whiteman M, Li QX, Halliwell B, Jenner AM, Wong BS, Laughton KM, Wenk M, Masters CL, Beart PM, et al: Chronic exposure to U18666A is associated with oxidative stress in cultured murine cortical neurons. J Neurochem 98: 1278-1289, 2006.

32. Circu ML and Aw TY: Reactive oxygen species, cellular redox systems, and apoptosis. Free Radic Biol Med 48: 749-762, 2010.

33. Resseguie EA, Staversky RJ, Brookes PS and O'Reilly MA: Hyperoxia activates ATM independent from mitochondrial ROS and dysfunction. Redox Biol 5: 176-185, 2015.

34. Skulachev VP: Cytochrome $\mathrm{c}$ in the apoptotic and antioxidant cascades. FEBS Lett 423: 275-280, 1998

35. Reubold TF and Eschenburg S: A molecular view on signal transduction by the apoptosome. Cell Signal 24: 1420-1425, 2012.

36. Allan LA and Clarke PR: Apoptosis and autophagy: Regulation of caspase-9 by phosphorylation. FEBS J 276: 6063-6073, 2009.

37. Espin R, Roca FJ, Candel S, Sepulcre MP, González-Rosa JM, Alcaraz-Pérez F, Meseguer J, Cayuela ML, Mercader N and Mulero V: TNF receptors regulate vascular homeostasis in zebrafish through a caspase-8, caspase-2 and P53 apoptotic program that bypasses caspase-3. Dis Model Mech 6: 383-396, 2013.

38. Gross A and Katz SG: Non-apoptotic functions of BCL-2 family proteins. Cell Death Differ 24: 1348-1358, 2017.

39. Wang X, Wu J, Yu C, Tang Y, Liu J, Chen H, Jin B, Mei Q, Cao S and Qin D: Lychee seed saponins improve cognitive function and prevent neuronal injury via inhibiting neuronal apoptosis in a rat model of Alzheimer's disease. Nutrients 9: pii: E105, 2017.

40. Tong Y, Bai L, Gong R, Chuan J, Duan X and Zhu Y: Shikonin protects $\mathrm{PC} 12$ cells against beta-amyloid peptide-induced cell injury through antioxidant and antiapoptotic activities. Sci Rep 8: 26, 2018.

41. Lai YC, Li CC, Sung TC, Chang CW, Lan YJ and Chiang YW: The role of cardiolipin in promoting the membrane pore-forming activity of BAX oligomers. Biochim Biophys Acta Biomembr 1861: 268-280, 2019.

42. O'Connell MA and Hayes JD: The Keap1/Nrf2 pathway in health and disease: From the bench to the clinic. Biochem Soc Trans 43: 687-689, 2015.

43. Chu $\mathrm{H}, \mathrm{Yu} \mathrm{H}$, Ren $\mathrm{D}$, Zhu K and Huang H: Plumbagin exerts protective effects in nucleus pulposus cells by attenuating hydrogen peroxide-induced oxidative stress, inflammation and apoptosis through NF-кB and Nrf-2. Int J Mol Med 37: 1669-1676, 2016.

44. Zhu L, Liu Z, Feng Z, Hao J, Shen W, Li X, Sun L, Sharman E, Wang $\mathrm{Y}$, Wertz $\mathrm{K}$, et al: Hydroxytyrosol protects against oxidative damage by simultaneous activation of mitochondrial biogenesis and phase II detoxifying enzyme systems in retinal pigment epithelial cells. J Nutr Biochem 21: 1089-1098, 2010.

45. Khalaj L, Nejad SC, Mohammadi M, Zadeh SS, Pour MH, Ahmadiani A, Khodagholi F, Ashabi G, Alamdary SZ and Samami E: Gemfibrozil pretreatment proved protection against acute restraint stress-induced changes in the male rats' hippocampus. Brain Res 1527: 117-130, 2013.

46. Kaur SJ, McKeown SR and Rashid S: Mutant SOD1 mediated pathogenesis of amyotrophic lateral sclerosis. Gene 577: 109-118, 2016 .
47. Kansanen E, Kuosmanen SM, Leinonen H and Levonen AL: The Keap1-Nrf2 pathway: Mechanisms of activation and dysregulation in cancer. Redox Biol 1: 45-49, 2013.

48. Qu Z, Zhang J, Yang H, Huo L, Gao J, Chen H and Gao W: Protective effect of tetrahydropalmatine against d-galactose induced memory impairment in rat. Physiol Behav 154: 114-125, 2016.

49. Jiang T, Sun Q and Chen S: Oxidative stress: A major pathogenesis and potential therapeutic target of antioxidative agents in Parkinson's disease and Alzheimer's disease. Prog Neurobiol 147: $1-19,2016$.

50. Xu T, Niu C, Zhang $X$ and Dong $M$ : $\beta$-Ecdysterone protects SH-SY5Y cells against $\beta$-amyloid-induced apoptosis via c-Jun $\mathrm{N}$-terminal kinase- and Akt-associated complementary pathways. Lab Invest 98: 489-499, 2018.

51. Kim DI, Lee KH, Gabr AA, Choi GE, Kim JS, Ko SH and Han HJ: A $\beta$-Induced Drpl phosphorylation through Akt activation promotes excessive mitochondrial fission leading to neuronal apoptosis. Biochim Biophys Acta 1863: 2820-2834, 2016.

52. Leuner K, Schütt T, Kurz C, Eckert SH, Schiller C, Occhipinti A, Mai S, Jendrach M, Eckert GP, Kruse SE, et al: Mitochondrion-derived reactive oxygen species lead to enhanced amyloid beta formation. Antioxid Redox Signal 16: 1421-1433, 2012.

53. Fujita K, Yamafuji M, Nakabeppu Y and Noda M: Therapeutic approach to neurodegenerative diseases by medical gases: Focusing on redox signaling and related antioxidant enzymes. Oxid Med Cell Longev 2012: 324256, 2012.

54. Islam MT: Oxidative stress and mitochondrial dysfunction-linked neurodegenerative disorders. Neurol Res 39: 73-82, 2017.

55. Fei M, Jianghua W, Rujuan M, Wei Z and Qian W: The relationship of plasma $A \beta$ levels to dementia in aging individuals with mild cognitive impairment. J Neurol Sci 305: 92-96, 2011.

56. Park SY and Ferreira A: The generation of a $17 \mathrm{kDa}$ neurotoxic fragment: An alternative mechanism by which tau mediates beta-amyloid-induced neurodegeneration. J Neurosci 25: 5365-5375, 2005

57. Reifert J, Hartung-Cranston D and Feinstein SC: Amyloid beta-mediated cell death of cultured hippocampal neurons reveals extensive Tau fragmentation without increased full-length tau phosphorylation. J Biol Chem 286: 20797-20811, 2011.

58. Bartus RT: On neurodegenerative diseases, models, and treatment strategies: Lessons learned and lessons forgotten a generation following the cholinergic hypothesis. Exp Neurol 163: 495-529, 2000.

59. Ferreira-Vieira TH, Guimaraes IM, Silva FR and Ribeiro FM: Alzheimer's disease: Targeting the cholinergic system. Curr Neuropharmacol 14: 101-115, 2016.

60. Deiana S, Platt B and Riedel G: The cholinergic system and spatial learning. Behav Brain Res 221: 389-411, 2011.

61. Lushchekina S, Kots E, Novichkova D, Petrov K and Masson P: Role of Acetylcholinesterase in $\beta$-amyloid aggregation studied by accelerated molecular dynamics. Bionanoscience 7: 396-402, 2017.

62. Nitta A, Itoh A, Hasegawa T and Nabeshima T: beta-Amyloid protein-induced Alzheimer's disease animal model. Neurosci Lett 170: 63-66, 1994.

This work is licensed under a Creative Commons Attribution-NonCommercial-NoDerivatives 4.0 International (CC BY-NC-ND 4.0) License. 